\title{
J D CROSSAN'S CONSTRUCT OF JESUS' "JEWISHNESS": A CRITICAL ASSESSMENT ${ }^{1}$
}

\author{
M. Cromhout \\ (University of Pretoria)
}

\begin{abstract}
The article focuses on J D Crossan's reconstruction of the historical Jesus and the content he assigns to Jesus" "Jewishness". Guided by Crossan's own work and the insights of ethnicity theory, the continuities and discontinuities between Crossan's Jesus and traditional "Judaism" are investigated. It is argued that there is very little that connects Crossan's Jesus with traditional "Jewish" ethnic identity. In the process it is also argued that Crossan provides no comprehensive analytical framework within which it can be explained what kind of "Jew" Jesus was.
\end{abstract}

\section{Introduction}

It is characteristic of the "Third Quest" that a lot of attention is drawn to Jesus' so-called "Jewishness" (Harrington 1987; Du Toit 2001). This assertion is problematic on two fronts. First, it is far better to refer to Jesus as a Judean, so it is more appropriate to speak of his "Judeanness". Second, and the main focus of this article, what it meant to be "Jewish" is something not really well understood. As Holmén (2001:154) argues the "crucial problem of the 'Third Quest' seems to be that it is not the least clear what 'Jewishness' means. Indeed, judged on the basis of different scholarly pictures of Jesus it can mean almost anything" (emphasis added). The problem that Holmén hi-lights is that a lot is being said about Jesus' "Jewishness" but in terms of content there does not exist some or other satisfactory analytical framework by which "Jewishness" can be measured.

Crossan (1991) for example, argues that Jesus was a "Jew", but he must be understood within the context of inclusive Hellenistic "Judaism's" synthesis of "Jewish" and Gentile tradition. Overall, Crossan's reconstruction of the historical Jesus does not therefore really fit in with the supposed character of the "Third Quest", but his work shares a common problem in that Biblical scholarship for the greater part does not have an appreciation of what informed the entire process of "Jewish" ethnic identity formation. If Jesus moved within the world of inclusive Hellenistic "Judaism's" synthesis of "Jewish" and Gentile tradition, what does this say about Jesus' "Jewishness"? What kind of "Jew" was he? What is characteristic of inclusive, as opposed to exclusive Hellenistic 
"Judaism"? Do both approaches qualify to be equally "Jewish" in the first century? These questions cannot be answered without an analytical framework and background that will explain one very important, but not so much explored aspect of Biblical scholarship - the question of ethnic identity. It is because such an analytical framework is absent that any attempt to say something about Jesus being this or that kind of "Jew" seems somewhat premature.

Bearing in mind the above mentioned problems, in the pages that follow, the most noticeable elements of Crossan's reconstruction will be analysed in further detail to see how he understands Jesus' "Jewishness". What content does he assign to Jesus' "Jewish" ethnic identity? What continuities or discontinuities exist with traditional "Judaism"? In analysing Crossan's reconstruction the insights of cultural anthropology will also be employed. Ethnicity theory has broadly recognised several cultural features that are important for ethnic identity. The cultural features include the following: 1) name, a corporate name that identifies the group; 2) myths of common ancestry, the group claims to be descendents of a particular person or group/family; 3) shared "historical" memories, the group points to common heroes and events of the past; 4) land, the group has actual or symbolic attachment to an ancestral land; 5) language, or local dialect; 6) kinship, members of the group belong to family units which in turn, demonstrate communal solidarity with the local community or tribe, and with the group as a national entity; 7) customs identifiable with that group; and 8) also its religion. To this may be added 9) phenotypical features, which points to genetic features (Duling 2005; Esler 2003:43-44). With the exception of the latter feature, which does not come into play (as "Jews" basically looked like everybody else in the Roman-Hellenistic world), those cultural features that are affected in the reconstruction of Crossan will be mentioned.

The choice to be also guided by the insights of ethnicity theory is quite intentional. From an analytical perspective it is a logical "map" to help route the analysis. At the same time, by using the cultural features listed above it will expose the reality that often scholars write about Jesus without realising that they do unconsciously say something about what kind of "Jew" Jesus was. The same is true also of those things that scholars do not say or omit from their reconstructions of the historical Jesus. Therefore any investigation into the "Jewishness" of Jesus will have to see how these cultural features receive treatment in various reconstructions. So what will concern us here is what Crossan regards as authentic Jesus tradition, and 
how this tradition affects the cultural features already listed. In his view, what kind of "Jew" was Jesus? What content, be it explicitly or implicitly, does he assign to Jesus" "Jewish" ethnic identity?

Crossan's approach to the historical Jesus is heavily influenced by the social sciences or the insights of cultural anthropology. Crossan puts Jesus and first century Palestine into the larger context of the "Brokered (Roman) Empire", which entailed the normal features of honour and shame, patronage and clientage. Jesus himself broke away from John the Baptist's eschatological message and announced the brokerless kingdom of God available to all in the present. Indeed, for Crossan, the heart of the Jesus movement was a shared egalitarianism of spiritual and material resources. But based on Crossan's reconstruction, can we at the end answer the question as to what kind of "Jew" Jesus really was?

\section{Jesus, Nazareth and Sepphoris}

The first matter that will be mentioned is Crossan's treatment of Nazareth. In what is to follow concerns the cultural feature of customs and general cultural identity. Archaeological investigations have uncovered tombs, the vast majority of which are chambers with a number of shafts cut horizontally into the walls in order that the body could be placed inside head first. The burial shafts or niches were called loculi graves in Latin and kokim graves in Hebrew. These kind of burial chambers are important since they virtually became the standard type of Jewish tomb from about 200 BCE. A conclusion Crossan (1991:16) draws from this is that "Nazareth was a very Jewish village in the Roman era." Other archaeological findings also suggest that the principle activity of villagers was agriculture. Crossan argues, however, that three qualifications must be added to the picture of Nazareth as a Jewish agricultural hamlet in the early Roman period.

First, there is the consideration of regional topography. The differences between Upper and Lower Galilee must be taken into account and the location of Nazareth in the southern most part of Lower Galilee. Compared to Upper Galilee, where the Meiron range reaches a height of almost four thousand feet, the four ranges of Lower Galilee reach heights of over one thousand feet. Lower Galilee would not have been as isolated as Upper Galilee. A rural agricultural Judaism would have been more characteristic of those living in the north, while some negative comments of later rabbis and clichés in the New Testament might suggest an accommodation to 
Hellenism in Lower Galilee. Nevertheless, Nazareth itself was located at an elevation of over one thousand feet on the southernmost hill of Galilee that "isolated the village off the beaten track" (Crossan 1991:17).

The second qualification that Crossan employs is political geography. A major city contains within its region various smaller cities that in turn serves a region with towns, each of which is surrounded by villages. The key factors that determine this settlement pattern are commerce and administrative functions. Crossan explains this hierarchy of settlement in Lower Galilee "was represented by Bethshan/Scythopolis as its major city, Sepphoris and Tiberias as its smaller cities, Capernaum and Magdala/Tarichaeae as its towns. Nazareth, clearly a village, is closest, not to one of those towns, but, at three or four miles distance, to Sepphoris, a smaller city" (Crossan 1991:17; emphasis original). The main west-east road through Galilee ran from Ptolemais on the Mediterranean coast through Sepphoris and Tiberias. Ptolemais itself was on the Via Maris, "that most ancient Palestinian highway of international commerce and conquest that opened Sepphoris and its environs to cosmopolitan influence" (Crossan 1991:18). Sepphoris was also the end point for the north-south road from Jerusalem, meaning that two roads carrying different types of influence converged there. Nazareth may have been off the beaten track but it was not far off a fairly well beaten track. So Nazareth must be understood in terms of its "relationship to an urban provincial capital" that amongst other things contained courts, a fortress, a theatre, ${ }^{3}$ a palace, a colonnaded street atop the acropolis, a royal bank and a population of around $30000^{4}$ (Crossan 1991:18-19).

Third, there is possibly the most important qualification, which comes from comparative demography. There was an unusually large number of urban and larger village centres in lower Galilee that made it one of the most densely populated regions of the Roman Empire. One is never more than a day's walk from anywhere in lower Galilee and hence any village could not escape the effects and ramifications of urbanization. Life in lower Galilee was as urbanized as any other part of the Roman Empire, but geographical proximity and demographic density also entailed cultural continuity. Any hostilities that existed between Sepphoris and Tiberias on the one hand, and rural areas on the other, were based on political disputes and not on a cultural split. A cultural continuum existed from city to country.

Based on the three considerations mentioned above Crossan concludes that the peasants of Nazareth "lived in the shadow of a major administrative 
city, in the middle of a densely populated urban network, and in continuity with its hellenized cultural traditions" (Crossan 1991:19). ${ }^{5}$ One cannot think of Jesus as a Galilean peasant as isolated, a "good old country boy", since the lives of Galileans were influenced by the all-pervasive presence of the Roman city. The significance of this Crossan does not develop here but it must be seen in connection with his argument that Jesus must be seen within the context of inclusive Hellenistic "Judaism", a matter that will be addressed later.

\section{Jesus and the brokerless Kingdom}

Now attention will be shifted briefly to Jesus' relationship with John the Baptist. Crossan accepts Jesus' baptism by John as one of the surest things we can know about both of them. Jesus, in submitting himself to John's baptism, initially accepted his apocalyptic expectation but thereafter changed his view of John's mission and message. From originally accepting John's message to await the coming of God as a repentant sinner, Jesus developed his own distinctive message and movement: it was now a question of being in the kingdom (Crossan 1991:232-238). To be more exact, it was a "brokerless kingdom" available in the present. The kingdom of God must be understood as people living under divine rule. It refers to a way of life or mode of being, not a nation or empire (human power) dependent on place (Crossan 1991:266). Of course, this affects the cultural features of land, customs and religion. Particularly in terms of the land, "Jewish" identity was inseparable from its relationship to the land. ${ }^{6}$ The gift of the land was a primary reason for Israel's existence and was part of God's covenant agreement with his people. So for the average "Jew", his/her relationship with God, indeed, his/her very identity was very much dependent on place. Here Jesus' understanding of the kingdom of God would be vastly different when compared with other "Jews". But how did this "landless" brokerless kingdom give expression to itself? Through magic and open commensality. And it is to these aspects of Crossan's reconstruction that we will turn next.

\section{Jesus the Magician}

Following the lead of Geza Vermes, Crossan places Jesus within the tradition of miracle working stemming from Elijah and Elisha, who apart from Jesus, was also given contemporary expression in the figures of Honi and Hanina. In contrast with Vermes, however, Crossan argues that "the title hasid is not appropriate, since ultra-strict observance of the law does 
not seem at all part of the constitutive identity of these wonder workers" and Crossan (1991:157) does not restrict the later development of the tradition to a northern (Galilean) provenance. Further, we are dealing "with a type of wonder worker who operates with certain and secure divine authority not mediated through or dependent on the normal forms, rituals, and institutions through which that divine power usually operates" and the dichotomy is that of "magician as personal and individual power against priest or rabbi as communal and ritual power" (Crossan 1991:157). To be more specific, before the Temple's destruction, "it was magician against Temple" and "magicians implicitly challenge the legitimacy of spiritual power" (Crossan 1991:157, 158; emphasis original). Hence, Crossan specifically deals with Jesus' miracles/magic as religious banditry. Crossan (1991:305) proposes that "magic is to religion as banditry is to politics" and "magic is unofficial and unapproved religion". Here three miracles will be discussed that Crossan regards as historical and which more directly pertains to the issue of Jewish ethnicity. ${ }^{7}$ Specifically, it affects the cultural features of customs and religion.

The first tradition we will discuss is Jesus' curing of a leper (EgerGos $2 b$ [35-47]; Mk 1:40-45 parr; Lk 17:11-19). The leper petitions Jesus, if the latter so wishes, to make him clean ("if you will"), and Jesus' response is "I will". Here Jesus' authority is set on par or even above that of the Temple, since Jesus can not only cure, but declare somebody cured ("clean") as well. But there is also the injunction to submit to the legal purity regulations of the Temple (Lv 12-14). Jesus both is and is not an obedient observer of levitical purity regulations. Crossan (1991:322) argues that a common source behind the tradition "already reversed and rectified the image of Jesus as an alternative to or negation of Mosaic purity regulations by that terminally appended injunction to legal fidelity". The Egerton Gospel intensified the vision of Jesus as a law observant teacher. Mark, on the other hand, intensifies the thrust of the original story. He has a leper as deeply reverential to Jesus, "has Jesus actually touch the leper, and qualifies the fulfilment of the purity regulations with the confrontation challenge 'as a witness to (against) them,' namely the priests ... For Mark, then, Jesus is precisely not a law-observant Jew" (Crossan 1991:323; emphasis original). Crossan accepts the possibility that the "touch" of the leper was a traditional part of the story; hence Jesus would have showed little respect or concern for purity regulations.

The other two traditions also deal with Jesus subverting the Temple monopoly. First, Jesus cures a paralytic and also declares his sins as 
forgiven. Besides the differences in place and detail, Crossan sees that behind John 5:1-9 and Mark 2:1-12 parr is a single traditional event. Here the conjunction between sickness and sin involves a terrible irony, especially in first-century Palestine. Excessive taxation, Crossan (1991:324) explains,

could leave poor people physically malnourished or hysterically disabled. But since the religiopolitical ascendancy could not blame excessive taxation, it blamed sick people themselves by claiming that their sins had led to their illnesses. And the cure for sinful sickness was, ultimately, in the Temple. And that meant more fees, in a perfect circle of victimization. When, therefore, John the Baptist with a magical rite or Jesus with a magical touch cured people of their sickness, they implicitly declared their sins forgiven or nonexistent. They challenged not the medical monopoly of the doctors but the religious monopoly of the priests. All of this was religiopolitically subversive.

The same is basically true of the third tradition where Jesus cures a blind man (Jn 9:1-7; Mk 8:22-26). Here Jesus as the Sent One uses spittle, and he sends the blind man to Siloam (meaning "Sent") to consummate the cure. For Crossan (1991:326), "a physical event for one man becomes a spiritual process for the world."

For the present purposes, the religious authority of the Temple is undermined and concerns over ritual purity are ignored. Jesus touches the leper, short-circuits the priests in the Temple and declares him as "clean", 8 and through healing he implicitly declares all the beneficiaries' sins as forgiven. ${ }^{9}$ Jesus engages in religious banditry, in opposition to the priests as representatives of communal and ritual power. Jesus' authority is set on an equal or even higher level than that of the Temple, which is seen as source of victimisation. Jesus also serves as an alternative or negation of Mosaic purity regulations, as well as the sacrificial cult, and therefore, aspects of the Torah itself. So for Jesus, the Temple and priesthood do not appear to be divinely appointed institutions in need of restoration. They were not a necessary means whereby covenant membership (= "Jewish" ethnic identity) could be maintained/restored as prescribed in the Torah. The role of the Temple and priests, also that of traditional covenant membership, becomes superfluous. So overall, Jesus subverts traditional "Jewish" ethnic identity in more than one respect. Jesus the wonderworker like Elijah and Elisha, Honi and Hanina, was not interested to observe the 
Law strictly. He was hardly "Jewish" in this respect.

\section{Jesus and open commensality}

Another expression of the brokerless kingdom was the nature of Jesus' table fellowship. This affects the cultural features of communal solidarity or kinship, customs and religion. Based on various traditions (Mk 2:18-20; Lk 7:31-35 // Mt 11:16-19; Lk 11:14-15, 17-18 // Mt 12:22-26; Mt 9:32-34; Mk 3:22-26), Crossan (1991:260) takes it to mean that John the Baptist lived an apocalyptic asceticism and that Jesus did the opposite. Jesus was accused of gluttony and drunkenness and of keeping bad company. But what exactly did Jesus do? Crossan finds an answer in the Parable of the Feast (GThom 64:1-2; Lk 14:15-24 // Mt 22:1-13). The various evangelists interpreted and applied the parable to their own situations but behind them all is a common structural plot. The parable concerns a person who gives an unannounced feast, sending friends to invite friends, who did not accept the invitation and who were then replaced by anyone off the streets. This "anyone" is very important to Crossan since it

negates the very social function of table, namely, to establish a social ranking by what one eats, how one eats, and with whom one eats. It is the random and open commensality of the parable's meal that is the most startling element. One could, in such a situation, have classes, sexes, ranks, and grades all mixed up together. The social challenge of such egalitarian commensality is the radical threat of the parable's vision ... And the almost predictable counteraccusation to such open commensality is immediate: Jesus is a glutton, a drunkard, and a friend of tax collectors and sinners. He makes, in other words, no appropriate distinctions and discriminations (Crossan 1991:262).

By making no appropriate distinctions and discriminations with whom he eats, we can say that Jesus was being very "unJewish" compared with the average demands of contemporary "Judaism". Similar accusations against Jesus are found elsewhere (POxy 1224 1224, 2.5.1, lines 1-5; Mk 2:13-17 parr; GEbion 1c; Lk 15:1-2). Crossan clusters seven other traditions around the ideal of open or egalitarian commensality, four of which will be discussed. First, there are two traditions that negate any value to food taboos or table rituals (GThom 14:3; Mk 7:14-15; Mt 15:10-11; Ac 10:14; 11:8 and GThom 89; Lk 11:39-41 // Mt 23:25-26). Together they also insist that the inside and what comes from the inside out are more 
important than the outside and what comes from the outside in. Jesus was not aiming here exclusively at the developed table rituals of the Pharisees though. Crossan (1991:262) explains that an "open table and an open menu offend alike against any cultural situation in which distinctions among foods and guests mirror social distinctions, discriminations, and hierarchies". But Jesus' viewpoint did offend the Pharisees. Jesus' accusations against the Pharisees in two traditions (GThom 39:1 \& POxy 655. 39:1; GThom 102; Lk 11:52 // Mt 23:13 and Lk 11:43 // Mt 23:6-7; Mk 12:38-40 parr) when seen in conjunction highlights the parallelism between food regulations and social hierarchy (Crossan 1991:262-263). So was Jesus for or against the ritual laws of "Judaism"? Crossan (1991:263) explains:

His position must have been, as it were, unclear. I propose ... that he did not care enough about such ritual laws either to attack or to acknowledge them. He ignored them, but that, of course, was to subvert them at a most fundamental level. Later, however, some followers could say that, since he did not attack them, he must have accepted them. Others, contrariwise, could say that, since he did not follow them, he must have been against them. Open commensality profoundly negates distinctions and hierarchies between female and male, poor and rich, Gentile and Jew.

Importantly, if Jesus does not really care about ritual laws (he ignores them), then he did not care about certain aspects of the Torah, the "constitution" so to speak of "Jewish" ethnic identity (= covenant membership). And if Jesus subverted ritual laws at their most fundamental level, then likewise did he subvert "Jewish" ethnic identity at its most fundamental level. What Crossan also implies is that open commensality profoundly negates distinctions and hierarchies between the ritually pure and unclean, between those who observe food/purity laws and those who do not (sinners and Gentiles). But ritual purity and food laws were primary ethnic identity markers for the cultural situation of "Jews" of the first century, including those that lived in Galilee. ${ }^{10}$ The average "Jew" adhering to them would not eat with sinners, much less with Gentiles both were "impure". Here, at times, Jesus ignored the dietary and purity laws and pretty much behaved like a "sinner" or Gentile, in other words, as one who was outside the realm of the covenant, outside the realm of common "Jewish" ethnicity. The kinship pattern of Jesus appears to be universal - any person is welcome to eat at his table, no matter what or 
how they eat.

But there was more to Jesus' association with undesirables. Jesus announced a kingdom for those who are like children. A "kingdom of children is a kingdom of nobodies" (Crossan 1991:269). Crossan finds corroboration for this picture in Jesus' following saying: "Blessed are you poor ( $\pi \tau \omega \chi 0\llcorner)$ for yours is the kingdom of God" (Lk 6:20 // Mt 5:3; GThom 54; cf Ja 2:5). Crossan (1991:272) brings attention to the fact that the Greek term $\pi \tau \omega \chi$ ó $\varsigma$ is a word that suggests "one who crouches", and so a "begger". "The $\pi \tau \omega \chi 0$ $\varsigma$ was somebody that lost his/her family and social ties. He/she was a wanderer, a foreigner to others, somebody who could not tax for any length of time the resources of a group to which he/she could contribute very little or anything at all. Based on the stratification of agrarian societies "Jesus spoke of a Kingdom not of Peasant or Artisan classes but of the Unclean, Degraded, and Expendable classes", put in another way, a "Kingdom of the Destitute" (Crossan 1991:273). Jesus likened this Kingdom to the spread of weeds (mustard and darnel) as seen from the angle of the landless poor, a Kingdom of undesirables. But the Kingdom of God needs the recognition of the Kingdom as present. "For Jesus", Crossan (1991:283) maintains, "a Kingdom of beggars and weeds is a Kingdom of here and now".

\section{Magic and meal coming together}

One of the most crucial aspects in Crossan's (1991:332-348) reconstruction is Jesus' mission charge to his disciples. He finds in three texts what he understands to be the place where one can see the heart of the Jesus movement (GThom 14:2; Luke 10:(1), 4-11 = Mt 10:7, 10b, 12-14; Mk 6:7-13 = Mt 10:1, 8-10a, $11=$ Lk 9:1-6): this entails mission, dress, place, commensality, healing, the Kingdom, and lastly itinerancy. It involves Jesus' instruction to his followers/disciples. They must go to people and share healing and the Kingdom in exchange for a meal. It entails the "conjunction of magic and meal, miracle and table, compassion and commensality" (Crossan 1991:332).

Of concern here, is Jesus' instruction to his disciples on how they should be dressed. This is relevant to the cultural feature of customs, but its aim affects religion as well. Crossan focuses on four items that is present in more than two independent sources: money/purse, sandals, bag, and bread. These items the disciples are not to take with them on their journey, although Mark allows the sandals which Crossan regards as a development 
in the tradition. In terms of these items Crossan (1991:338) says one immediately "notices a very striking anomaly precisely against the general background of Greco-Roman Cynicism". ${ }^{2}$ The recognisable dress of the counter-cultural Cynics included a cloak, wallet/bag (pera) and a staff, and their life typically included barefoot itinerancy (Crossan 1991:81). The pera's function was especially to denote their self-sufficiency. But Crossan finds in Jesus' instructions the opposite; the disciples must carry no bag, no bread, that is, no food for their journey. Crossan (1991:339) proposes the bag's prohibition "goes back to Jesus and that it must be explained in terms of the functional symbolism of the social movement he was establishing". The reason why there is no bag is because the missionaries were not to be self-sufficient. Crossan explains the missionaries will "share a miracle and a Kingdom" to "receive in return a table and a house." It is here, that Crossan (1991:341) suggests, where one can find "the heart of the original Jesus movement, a shared egalitarianism of spiritual and material resources ... it concerns the longest journey in the Greco-Roman world, maybe in any world, the step across the threshold of a peasant stranger's home". The point of the exercise was commensality, not alms wages, charges or fees.

For Jesus ... commensality was not just a strategy for supporting the mission ... Commensality was, rather, a strategy for building or rebuilding peasant community on radically different principles from those of honor and shame, patronage and clientage. It was based on egalitarian sharing of spiritual and material power at the most grass-roots level. For this reason, dress and equipment appearance was just as important as house and table response. (Crossan 1991:344)

Now what exactly are the implications for Jesus' ethnicity? One might say that combining "magic and meal", to enact the unbrokered Kingdom, to use Crossan's own words, would have a double impact on the subversion of the Temple authority, and on purity and food regulations, thus, on aspects of the Torah itself. Combined with the peculiar dress code (for example, does Crossan have itinerant Jesus and his disciples walking around barefoot? and if so, what does it mean?), "Jewish" ethnic identity as defined and lived out in the first century stood under fierce attack. What we have here is a basic disregard for what covenant membership normally required. Both the "brokered" "Jewish" Temple State and the social and religious discrimination Jesus opposes was part of mainstream "Judaism" and generally sanctioned by the Torah. The "Jewish" ethnicity Jesus now envisages - a community of equals - has no need of a sacrificial cult, social 
hierarchy or discrimination of any sort. Jesus and his disciples are permanent and wilful "apostates" in this regard, since Crossan (1991:349) presumes "that dress and itinerancy, miracle and table, healing and commensality, characterised Jesus as much as his missionaries and that they characterised them not just once but all the time. 'Mission' is thus much more than a single one-time sending of some set group". But it must be mentioned that Crossan places these counter-cultural features of Jesus' "mission" within a context of peasant society just as much over and against the ethos of the Greco-Roman world as he does his "Jewish" social world.

As already suggested, this radical "mission" of Jesus happened to bring him into conflict with the Temple as institution. John the Baptist also offered an alternative to the Temple but from another fixed location, from desert and Jordan rather from Zion and Jerusalem. Crossan (1991:346) sees in the itinerancy of Jesus' movement a radical nature because it is a symbolic representation of unbrokered egalitarianism. Jesus was

atopic, moving from place to place, he coming to the people rather than they to him. This is an even more radical challenge to the localized univocity of Jerusalem's Temple, and its itinerancy mirrored and symbolized the egalitarian challenge of its protagonist. No matter, therefore, what Jesus thought, said, or did about the Temple, he was its functional opponent, alternative, and substitute: his relationship with it does not depend, at its deepest level, on this or that saying, this or that action (Crossan 1991:355).

For Crossan, however, Jesus did symbolically enact and say something about the Temple's destruction (GThom 71; Mk 14:55-59 par; Mk 15:2932 parr; Ac 6:11-14; Jn 2:18-22). Crossan (1991:359) proposes that the earliest recoverable stratum involved an action that symbolically destroyed the Temple (Mk 11:15-16; Jn 2:14-16), accompanied by a saying announcing what was happening, "I will destroy this house utterly beyond repair" (GThom 71). Crossan proposes that poor Galilean peasants did not go up and down regularly to the Temple feasts. Crossan (1991:360) thinks

it quite possible that Jesus went up to Jerusalem only once and that the spiritual and economic egalitarianism he preached in Galilee exploded in indignation at the Temple as the seat and symbol of all that was nonegalitarian, patronal, and even oppressive on both the religious and the political level. His 
symbolic destruction simply actualized what he had already said in his teachings, effected in his healings, and realized in his mission of open commensality.

Crossan explains in conclusion that the symbolic destruction was but the logical extension of the miracle and table conjunction, of open healing and open eating.

Naturally, this conjunction of open healing and open eating, that culminates in opposition to the Temple, places Jesus and his followers in discontinuity with common "Judaism" of their day. They become like Mediterranean peasant philosophers, who, within the context of "Judaism", offer healing and forgiveness, acting as substitutes or opponents of the Temple, indeed, as opponents of a patronal, brokered, hierarchical and exclusive "Judaism". Jesus also symbolically destroys the Temple with no vision to rebuild it. As mentioned already, the Temple and priesthood were not a necessary means whereby covenant membership (= "Jewish" ethnic identity) could be maintained/restored as prescribed in the Torah. Further, there would be no need for pilgrimage festivals. So much for remembering God's deliverance at Passover, or bringing agricultural offerings in thankfulness of God's generous provision through the land (this also affects the cultural features of shared "historical" memories and myths of common ancestry). Jesus and his disciples give no credence to dietary and purity laws, honour and shame, and offer healing and the kingdom in exchange for a meal, an extension of their open commensality. Again, they are ignoring certain requirements of the Torah and what "Jewish" ethnicity of the day required. Indeed, be it by accident or design, the borders are shifted whereby "sinners" and Gentiles can be included within the fellowship. Jesus and his followers are redefining "Jewish" ethnic identity based on a spiritual, social and economic egalitarianism, which could potentially even include the traditional "outsiders".

\section{Jesus and the patriarchal family}

So how does radical egalitarianism affect the family? Of course, this concerns the cultural feature of kinship. Crossan initially refers to two traditions to answer this question (GThom 79:1-2; Lk 11:27-28; Jn 13:17; Ja 1:25 and GThom 99; Mk 3:19-21, 31-35 parr; 2 Clem 9:11; GEbion 5). It is not the womb who carried Jesus who is blessed, but those who do the will of God. Jesus further declares that it is his followers who are his real family (1991:299). Crossan also alludes to the tradition that Jesus said he 
was to bring not peace, but a sword (GThom 16; Lk 12:51-53 // Mt 10:3436). Jesus was to bring division within families. But Crossan (1991:300) argues the point of this tradition is not about those who believe in Jesus and those who do not. "It is, just as in Micah 7:6, the normalcy of familial hierarchy that is under attack." The strife is between generations and in both directions. "Jesus will tear the hierarchical or patriarchal family in two along the axis of domination and subordination" 13 and "even more significant, is that the division imagined cuts across sex and gender". The same point is made in the tradition about hating one's family (GThom 55:1-2; 101; Lk 14:25-26 // Mt 10:37). Thus by being against the patriarchal family Jesus' egalitarian vision extends to the family as well.

In Jesus' teaching against divorce (1 Cor 7:10-11; Lk 16:18 // Mt 5:31-32; Mk 10:10-12 par; Herm Man 4.1:6, 10) sharp focus is brought to the honour of a wife. In Jewish law at the time of Jesus, a wife was not allowed to initiate divorce proceedings, but more to the point, Jesus says against the norm that a man can commit adultery against the wife. The honour of the wife is to be as much protected as that of the husband. So it was not merely a teaching against divorce but an attack on androcentric honour. Its negative effects went far beyond divorce for it was the basis of the dehumanisation of women, children, and non-dominant males. For Crossan (1991:302), "Jesus sets parents against children and wife against husband, sets, in other words, the Kingdom against the Mediterranean. But not just against the Mediterranean alone".

The breakdown of the patriarchal family also comes into play when Crossan treats Jesus' relationship with his own hometown (Nazareth) and his family, especially his brothers (GThom 31 \& POxy 1.31; Mk 6:1-6 par.; Lk 4:16-24; Jn 4:44). A prophet does not get honour from his own hometown and relatives. But Crossan does not see the tension as about belief in Jesus; it is about brokerage. Here we simply have Jesus' own experience of what he said about bringing division in families. Crossan (1991:347) argues that if Jesus "was a well-known magician, healer, or miracle worker, first, his immediate family, and, next, his village, would expect to benefit from and partake in the handling of that fame and those gifts. Any Mediterranean peasant would expect an expanding ripple of patronage-clientage to go out from Jesus ... in turning his back on Nazareth and on his family [Jesus repudiated] such brokerage ...".

For our purposes here, Crossan's interpretation allows for Jesus to be seen as again subverting or redefining "Jewish" ethnic identity. For example, 
obligations to parents was a divine command. Kinship patterns, here the patriarchal family, crucial to social and ethnic identity, stands to be obliterated. If the approach to Crossan is correct, a brokerless kingdom involves not a brokered ethnic family, but a brokerless spiritual family where all are regarded as equals.

\section{Jesus and inclusive "Judaism"}

Crossan (1991:417-418) insists that Jesus must be understood within his contemporary Judaism. But as far as he is concerned, there was in the time of Jesus only one sort of Judaism, namely Hellenistic Judaism. ${ }^{14}$ It was a Judaism that responded to Greco-Roman culture. Crossan further distinguishes between exclusive and inclusive Judaism, or between exclusive and inclusive reactions to Hellenism. By inclusive Judaism Crossan understands a Judaism "seeking to adapt its ancestral customs as liberally as possible with maximal association, combination, or collaboration with Hellenism on the ideological level" but he also admits that inclusivity "at its extreme, can mean abdication, betrayal, and disintegration" (Crossan 1991:418). Crossan also brings attention to the writings of Jews and Gentiles and what they had to say about one another it was not always nice reading, in both directions, but at times it was positive. It is on the latter that Crossan focuses on, specifically on two ideological issues, the understanding of God and the question of morality. Crossan explains that in the Letter of Aristeas (latter second-century BCE), it is explained that Jews and pagans worship the same God, although under different names. And an unknown Jew, writing probably in Alexandria somewhere between $30 \mathrm{BCE}$ and $40 \mathrm{CE}$, writes about adultery, homosexuality and infanticide. The Sentences of Pseudo-Pholyclides speaks against those three issues, but for Crossan the Sentences are based on a more inclusive vision of Judaism and paganism. Why? It presumes a superior ethic not only from exclusively Jewish revelation but from natural law commonly available to all (Crossan 1991:419-420). Now Crossan (1991:420) proceeds by asking the following three intriguing questions:

First, left to itself, what would have happened to the dialectic of exclusive and inclusive Judaism? Second, left to itself, would Judaism have been willing to compromise on, say, circumcision, in order to increase missionary possibilities among Greco-Roman pagans? Or, again, if paganism conceded on divinity and morality, could Judaism have conceded on intereating and intermarrying? Third, left to itself, could Judaism have converted 
the Roman Empire? ... Moot questions because, of course, the process was not left to itself. Within sixty-five years, first in 7073, next in 113-115, and finally in 132-135 C.E., Judaism in, respectively, Palestine, Egypt and its environs, and Palestine again, rose against Rome.

The effects of these were of course the destruction of the Temple in Jerusalem and Judea was proscribed to Jews, and eventually, rabbinical Judaism emerged along with the ascendancy of exclusive over inclusive Judaism.

Now of relevance to the present investigation is that Crossan regards the questions he posed as important, since he interprets Jesus "against the background of inclusive rather than exclusive Judaism", "a peasant, oral and popular praxis of what might be termed ... a Jewish Cynicism" (Crossan 1991:421). Crossan (1991:421) continues by saying it "involved practice and not just theory, life-style and not just mind-set in opposition to the cultural heart of Mediterranean civilization, a way of looking and dressing, of eating, living, and relating that announced its contempt for honor and shame, for patronage and clientage. They were hippies in a world of Augustan yuppies. Jesus and his followers ... fit very well against that background" (emphasis original). Jesus was also closest to a magician type figure, and in consequence, Crossan argues we are forced to bring together two disparate elements: healer and Cynic, magic and meal.

The historical Jesus was, then, a peasant Jewish Cynic. His peasant village was close enough to a Greco-Roman city like Sepphoris that sight and knowledge of Cynicism are neither inexplicable nor unlikely ... His strategy, implicitly for himself and explicitly for his followers, was the combination of free healing and common eating, a religious and economic egalitarianism that negated alike and at once the hierarchical and patronal normalcies of Jewish religion and Roman power ... He was neither broker nor mediator ... Miracle and parable, healing and eating were calculated to force individuals into unmediated physical and spiritual contact with God and unmediated physical and spiritual contact with one another. He announced, in other words, the brokerless kingdom of God (Crossan 1991:421-422; emphasis original).

Crossan (1991:422) argues that "Jesus, as a peasant Jewish Cynic, was 
already moving, but on a popular level, within the ambience of inclusive Judaism's synthesis of Jewish and Gentile tradition." Unfortunately, Crossan does not give a comprehensive explanation of what inclusive or exclusive "Judaism" involves. Was the former limited to matters of God and morality? And how did inclusive or exclusive "Judaism" actually operate in the real world, particularly in Galilee, and by whom? ${ }^{15}$ But without a doubt Crossan's reconstruction of Jesus estranges him from firstcentury "Jewish" ethnic identity in a dramatic way. Although "Judaism" was influenced by Hellenism, it was very much geared at achieving the opposite than a synthesis of "Jewish" and Gentile tradition (particularly when it came to crucial matters of land, kinship, customs and religion). If Jesus' egalitarianism "negated alike and at once the hierarchical and patronal normalcies of Jewish religion" then Jesus negated important aspects of "Jewish" ethnic identity. Jesus is counter-cultural to various aspects of what the God of Israel traditionally required for covenant membership. The "Jewish constitution", the Torah, Yahweh's gift to his people, is under attack. But Crossan's understanding of the situation of Nazareth and Sepphoris allows for Jesus to be located within the ambience of an inclusive "Judaism". Jesus was socialized to become, ideologically, an inclusive "Jew", not to be Torah-obedient as such. Jesus in a sense appears to be more "universally spiritual" and less "Jewish". Jesus does not want to fix what was "broken"16 - he abandons primary "Jewish" institutions altogether. He was a product of cultural continuity between rural and urban areas of Lower Galilee, itself part of the larger sea of Hellenism and the Roman Empire that gave opportunity for a synthesis between "Jewish" and Gentile Hellenistic tradition.

\section{Summary: JD Crossan - Jesus a Mediterranean "Jewish" peasant}

Crossan's reconstruction has very little that connects Jesus with traditional "Jewish" ethnicity in the first century. (Of course, Crossan's historical Jesus would stand in continuity with his notion of inclusive Hellenistic "Judaism".) Jesus appears more as a peasant Mediterranean philosopher than a peasant "Jewish" prophet or sage, and his immediate "Jewish" background is stretched very thin over the ethos of the Roman-Hellenistic empire. Where continuity exists is Jesus' faith in God, but not the God peculiar to Israel as such, since Greeks and Romans can also know God albeit under different names. Nazareth was also a "Jewish" village, but it must be seen as in continuity with Sepphoris and its Hellenized cultural traditions. In addition, Jesus illustrates a strong community solidarity with socially marginalized "Jews", but one gets the impression this is 
ideologically not reserved for "Jews" alone. There is an openness that could potentially even include the "sinners" and the Gentiles.

Besides the above, after Jesus was baptised by John, Jesus broke away from his eschatological message and concerned himself with the brokerless kingdom of God that is available in the present. It involves those people who place themselves under divine rule - it is not dependent on a nation or place. Jesus challenged the legitimacy of the Temple's spiritual (and communal and ritual) power and engages in religious banditry. Through Jesus' healings/magic, he is placed on par or even above the authority of the Temple, and he implicitly forgives the beneficiaries their sins. He touches lepers and makes them "clean", and so serves as an alternative or negation of the Mosaic purity regulations. In fact, he ignores purity rules. In open commensality, Jesus shows he has no interest in making appropriate distinctions and discriminations. He negates the value of food taboos and table rituals. "Jews" of different classes and sexes are free to eat together, their ritual status being irrelevant.

When magic and meal come together, the "mission" of Jesus (and his followers) to enact the brokerless kingdom requires a peculiar dress code, in some ways similar (yet different) to Greco-Roman Cynicism. Jesus and his followers are (barefoot?) itinerants as opposed to the localised Temple. Jesus serves as the Temple's functional opponents and its substitute - by implication, also to the Torah in some respects. When Jesus was in Jerusalem he symbolically destroyed it and said he would destroy it beyond repair. Jesus was also against the brokered and patriarchal family. He brought division between the generations, and set a wife against her husband - similar tension Jesus experienced with his own family. Jesus sets up an alternative kinship pattern based on egalitarian principles. Lastly, Jesus moved within the ambience of inclusive Hellenistic "Judaism's" synthesis of "Jewish" and Gentile tradition. Inclusive "Judaism" recognised that it had common ground with some Gentile traditions, such as the understanding of God and questions of morality. Overall, Jesus is a peasant "Jewish" Cynic, who sets the kingdom - a religious, social and economic egalitarianism not dependent on place or nation - in opposition to the Mediterranean and "Jewish" ethos of honour and shame, patronage and clientage.

So if Jesus was a peasant "Jewish" Cynic, a counter-cultural figure, what does that mean for Jesus' ethnic identity? Crossan by no means denies that Jesus was a "Jew", yet his reconstruction with a very strong element of 
discontinuity with traditional "Judaism", does have some profound implications for Jesus' "Jewish" identity. A counter-cultural and Hellenised figure such as Jesus, in opposition to a hierarchical and brokered "Judaism" as he was, needs to be analysed in terms of an overall interpretive framework that more or less gives guidelines for a "common Judaism". If such a guideline is in place, only then will it be possible to determine what kind of "Jew" Crossan's Jesus really was.

\section{WORKS CONSULTED}

Allison, D.C. 2000

The intertextual Jesus: Scripture in $Q$. Harrisburg: Trinity Press International.

BDAG 2000

A Greek-English Lexicon of the New Testament and other Early Christian literature. 3rd ed of BAGD, revised by Danker, F W.

Chicago: University of Chicago Press.

Berger, P.L. 1973

The social reality of religion. Penguin University Books.

Berger, P.L. \& Luckmann, T. 1967

The social construction of reality: A treatise in the sociology of knowledge. New York: Anchor Books.

Borg, M.J. 1994

Jesus in contemporary scholarship. Valley Forge: Trinity Press International.

Brueggemann, W. 2002

The land: Place as gift, promise, and challenge in Biblical faith. 2nd ed. Minneapolis: Fortress Press.

Cromhout, M. \& Van Aarde, A.G. 2006

A socio-cultural model of Judean ethnicity: A proposal. HTS (62)1, 69-101.

Chancey, M.A. 2001

The cultural milieu of ancient Sepphoris. NTS 47(2), 127-45.

Chancey, M.A. 2002

The myth of a Gentile Galilee. Cambridge: Cambridge University Press.

Chancey, M. \& Meyers, E.M. 2000

How Jewish was Sepphoris in Jesus' time? BAR 26(4), 18-33, 61. Cohen, S.J.D. 1987

From the Maccabees to the Mishnah. Philadelphia: The Westminster Press. 
Crossan, J.D. 1991

The historical Jesus: The life of a Mediterranean Jewish peasant. New York: Harper San Francisco.

Duling, D.C. 2005

Ethnicity, ethnocentrism, and the Matthean ethnos. BTB 35(4), 125143.

Dunn, J.D.G. 1990

Jesus, Paul and the law: Studies in Mark and Galatians.

Louisville: Westminster/John Knox Press.

Du Toit, D.S. 2001

Redefining Jesus: Current trends in Jesus research, in Labahn, $\mathrm{M}$ and Schmidt, A (eds), Jesus, Mark and Q, 82-124. Sheffield: Sheffield Academic Press.

Eshel, H. 2000

They're not ritual baths. BAR (26)4, 42-45.

Esler, P.F. 2003

Conflict and identity in Romans: The social setting of Paul's Letter. Minneapolis: Fortress Press.

Elliott, J.H. 2002

Jesus was not an egalitarian. A critique of an anachronistic and idealist theory. BTB 32(2), 75-91.

Guijarro, S. 2004

The family in the Jesus movement. BTB 34(3), 114-121.

Hanson, K.C. 1999

The Galilean fishing economy and the Jesus tradition. BTB 27, 99-111. Harrington, D.J. 1987

The Jewishness of Jesus: facing some problems. $C B Q 49,1-13$.

Hengel, M. 1989

The 'Hellenization' of Judaea in the first century after Christ. transl. by Bowden, J. London: SCM Press; Philadelphia: Trinity Press International.

Holmén, T. 2001

The Jewishness of Jesus in the "Third Quest', in Labahn, M. and Schmidt, A. (eds), Jesus, Mark and Q, 143-162. Sheffield: Sheffield Academic Press.

Meyers, E.M. 2000

Yes, they are. BAR 26(4), 46-49, 60-61.

Reed, J.L. 2000

Archaeology and the Galilean Jesus: A re-examination of the evidence. Harrisburg: Trinity Press International.

Reich, R. 2002 
They are ritual baths. BAR 28(2), 50-55.

Schmidt, F. 2001

How the temple thinks: Identity and social cohesion in Ancient Judaism. transl. by Crowley, J.E. Sheffield: Sheffield Academic Press. Stegemann, E.W. \& Stegemann, W. 1999

The Jesus movement: A social history of its first century. transl. by Dean, O C. Edinburgh: T\&T Clark.

\section{NOTES}

1 This is the second of two articles that investigate how historical Jesus scholarship explains Jesus' "Jewishness". The first article focussed on the work of J P Meier. These articles are based on Markus Cromhout's PhD dissertation, entitled "The reconstruction of Judean ethnicity in Q." The dissertation was prepared under the supervision of Prof Dr Andries G van Aarde, Professor Emeritus, Faculty of Theology, University of Pretoria (2006).

2 Here I agree with Pilch (1997) who argued that it is anachronistic to speak of "Jews" (or even "Christians") in the first century. As Esler (2003:63-72) also pointed out, it was normal practice in antiquity that people were named after the territory from which they originated. The BDAG (2000) also prefer the terms "Judean" and "Judeanism". For the purposes of this article, the terms "Jew/Jewish" and "Judaism" will be retained, however.

3 It is doubtful that the theatre was built in Jesus' time. The theatre probably dates to the late first or early second century CE (Chancey \& Meyers 2000:24; Chancey 2002:75).

4 Reed $(2000: 80,82)$ estimates that Sepphoris had a population of around 8 000 to 12000 inhabitants.

5 Here the remarks of Hengel are ever important. What is meant by "Hellenistic" should be defined more precisely; for example, does it refer to oriental syncretism, or does "it refer to technology, art, economics, politics, rhetoric and literature, philosophy or religion?" What was impossible was a Jewish pagan cult, the denial of monotheism, the failure to observe the Torah and the desecration of the Temple (Hengel 1989:54).

6 Brueggemann (2002:3) even contends that land "is a central, if not the central theme of biblical faith" (emphasis original). Israel's history is a recurring cycle, moving from land to landlessness, from landedness to land. The land for which Israel yearns "is always a place with Yahweh, a place well filled with memories or life with him and promise from him and vows to him. It is land that provides the central assurance to Israel of its historicality, that it will be and always must be concerned with actual rootage in a place that is a repository for commitment and therefore identity ... It will no longer do to talk about Yahweh and his people but we must 
speak about Yahweh and his people and his land" (Brueggemann 2002:5; emphasis original).

The miracles that according to the Gospels Jesus performed for Gentiles at a distance (Lk 7:1-2 // Mt 8:5-10, 13; cf Jn 4:46-53 and Mk 7:24-30; Mt 15:21-23, 25-28) Crossan regards as "programmatic defenses of the later Gentile mission, as Jesus' proleptic initiation of that process ... Early Christian communities symbolically retrojected their own activities back into the life of Jesus" (Crossan 1991:328).

The notions of the sacred and the profane, of the pure/clean and impure/unclean, were important elements of the "Jewish" symbolic universe (cf Berger \& Luckmann 1967; Berger 1973; Cromhout \& Van Aarde 2006). It was especially the role of the priests to distinguish (badal) between the two ( $\operatorname{Lv} 10: 10)$ and which had to be taught to the people (Ezk 44:23). Impurity could be acquired through transgressing the Law, but essentially had to do with the changes of status. According to the "Jewish" symbolic universe, there was a certain order to Creation; everything had its proper place: "What is at one and the same time intact and in its place is pure, tahor. Conversely, what is impure, tame, presupposes mixture and disorder. Hence the attention given to extreme situations, to the margins, to beginnings and ends, to the frontiers of otherness in all its forms ... Thus the margins of the body are dangerous. The skin diseases, bodily secretions, the emissions of sperm and blood, excrement, by blurring the frontiers between the interior and the exterior, threaten physical integrity" (Schmidt 2001:91).

9 Forgiveness of sins was normally obtained through the sacrificial cult ("guilt offerings") of the Temple. See Leviticus 4-6.

10 The laws on clean and unclean foods do not hold such a central place in the Torah (Lv 11:1-23; Dt 14:3-21). Even Jacob's sons ate Gentile food with Gentiles (Gn 43:32). From the time of the Maccabees, however, food laws took on increasing importance in "Jewish" folklore and "Jewish" selfunderstanding (Dunn 1990:193).

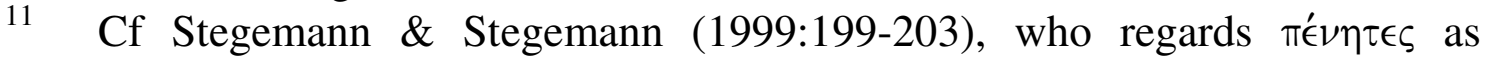
denoting the relatively poor and $\pi \tau \omega \chi 0 i$ as the absolutely poor. For the time of their nomadic existence, Jesus and his disciples (some of whom were fishermen) belonged to the latter - although, under normal circumstances, the $\tau \epsilon^{\prime} \kappa \tau \omega \nu$ Jesus and his initial disciples as $\dot{\alpha} \lambda \iota \epsilon \hat{\epsilon} \zeta$ could also have been very poor. For the dynamics of the fishing industry in Galilee, see Hanson (1999).

12 Another and more probable background is Moses' instructions to the Israelites and their departure from Egypt. Exodus 12:11 explains that Moses instructed the Israelites to eat the Passover in a hurry, with sandals on their feet and staff in hand, while Exodus 12:34-36 (cf Gn 15:14; $1 \mathrm{Sm}$ 
4-6) recalls that they left Egypt with bread, silver and gold, and with clothing (cf Allison 2000:42-43). social distinctions (or ranking/class), discriminations and hierarchies. Here it is applied to the family. Borg understands Jesus along similar lines. One aspect of Borg's (1994:151) understanding of the historical Jesus is that he was a teacher of an "alternative wisdom". One area of that alternative wisdom undermined the conventional wisdom of the patriarchal family. Indeed, Jesus' anti-family sayings illustrate that Jesus was no champion of (patriarchal) family values. Borg (1994:107) maintains the "invitation was to break with the patriarchal family - an oppressive hierarchical structure mirroring the society as a whole". Elliott has responded to such arguments, in particular against Crossan, that such an egalitarian reading of Jesus towards the family (and egalitarianism in general) is an idealist fallacy. It is an interpretation that appears more eisegesis than exegesis, an anachronistic reading of modern notions into the biblical texts (something which Crossan pre-emptively denied, as he claims egalitarianism was deeply rooted in peasant society). Jesus' invitation to abandon family, property, possessions, occupations, and protection, Elliott maintains, says nothing about the family as an institution in itself. It is simply the re-ordering of conventional priorities. "In these sayings Jesus issues no condemnation of the family as such. He only declares the biological family to be of secondary significance or indifference in light of the imminent commencement of God's reign" (Elliott 2002:78-79). Jesus had a positive conception of the family as an institution, gave positive attention to it, and he used it as a model to define life under God's reign (cf Guijarro 2004:118) and overall, differences of age, gender, class and ethnicity remained as demarcations of identity and status and Jesus "urged conduct that would relativise but not eliminate such disparities" (Elliott 2002:85-86). The hallmark of the reign of God, the heavenly patriarch, was a "radical inclusivity" that "relativized all conventional lines of discrimination and exclusion", not a "radical egalitarianism" where the family and its structure of authority disappears (Elliott 2002:87). Guijarro brings another angle to the reason why Jesus broke ties with the family. Jesus and his disciples broke their family ties not to criticize patriarchal structures but to assume the lifestyle conditions of the peasantry, particularly landless peasantry. By becoming wandering beggars themselves, Guijarro (2004:117) suggests, they, as coming from a more upper class, would have seemed more credible to peasants that lived in a similar situation in society where poverty meant the lack of family support. Guijarro (2004:116) also argues that the "success that Jesus' preaching had among peasant masses that followed him would be very difficult to explain if he had a clearly anti-familial attitude. The family was 
not only the basis of Israelite society, but also the main source of identity among individuals, so that an attack on the family would be interpreted as an attack on traditional societal values and on the Israelite religion."

Cf Cohen (1987:37) who argues that all forms of Judaism - of both the Diaspora and in the land of Israel - were Hellenised; there was no pure Judaism. "'To Hellenize or not to Hellenize' was not a question the Jews of antiquity had to answer. They were given no choice. The questions that confronted them were 'how?' and 'how far?' ... How far could Judaism go in absorbing foreign ways and ideas before it was untrue to itself and lost its identity?" (Cohen 1987:45).

Crossan's understanding here of the cultural dynamics of Nazareth and Sepphoris and its "hellenized cultural traditions" is not strongly supported by the archaeological evidence. Sepphoris was certainly Hellenized in terms of its public architecture, form of government, and use of the Greek language. Public architecture is of course more instructive as to the ruler's cultural orientation than that of the ordinary people (Reed 2000:43). And generally, archaeological investigations have revealed that Sepphoris was overwhelmingly inhabited by "Jews" (Chancey 2001; 2002:79-80). The four "religious", or rather, ethnic indicators that have been found all over Galilee (lack of pork in the bone profile, miqva'ot, stone vessels, and burial in kochim or loculi tombs with ossuaries) are also present in the excavations conducted in Sepphoris. Objections have been raised that the pools in Sepphoris be identified as miqva'ot (Eshel 2000), but it seems to be generally accepted that the pools are such (Meyers 2000; Reich 2002). Reed (2000:135) also argues that theories of Greek education or Cynic philosophical schools at Sepphoris are implausible since the city was not home to a significant number of Romans or Greeks.

This statement must be understood quite liberally. It points to Jesus' apparent lack of willingness to be a reformer within "Jewish" society and remaining within the "Jewish" institutional order. 